\title{
EVALUASI MILLENIUM DEVELOPMENT GOALS (MGDs) DALAM MENANGGULANGI KEMISKINAN DAN KELAPARAN MENUJU SUSTAINABLE DEVELOPMENT GOALS (SGDs) DI KOTA MEDAN
}

\author{
Dede Ruslan \\ Fakultas Ekonomi Universitas Negeri Medan \\ Email: dras_ruslan@yahoo.com
}

\begin{abstract}
Program Millennium Development Goals (MDGs) have ended in 2015, Indonesia's commitment to achieve the MDGs is done by making the MDGs as a reference inpreparation of documents National Long-Term Development Plan (RPJPN) 2005-2025. To examine the implementation of the Sustainable Development Goals (SDGs) must be evaluated how the condition of development gains in Medan via indicator Millienium Development Goals (MDGs) that specifically alleviate poverty and hunger (goal 1 MDGs) so it can be recommended several measurement programs that can affect target-setting achievements of Sustainable Development Goals (SDGs) in Medan. Data analysis techniques used to approach the quantitative approach, but in the scope of descriptive analysis by exploring the data in the form of tables and graphs. The results showed that the conditions of development gains in Medan via indicator Millienium Development Goals (MDGs) basically has been running well in which of the seven indicators that proclaimed the majority of activity has been reached.
\end{abstract}

Keywords : Sustainable Development Goals (SDGs), poverty and hunger (goal 1 MDGs).

\section{PENDAHULUAN}

D rogram Millennium Development Goals (MDGs) telah berakhir pada tahun 2015, Komitmen Indonesia untuk mencapai tujuan MDGs dilakukan dengan menjadikan MDGs sebagai acuan dalam penyusunan dokumen Rencana Pembangunan Jangka Panjang Nasional (RPJPN) 2005-2025, Rencana Pembangunan Jangka Menengah Nasional (RPJMN) 2004-2009 dan 2010-2014, Rencana Kerja Pemerintah (RKP) 
Tahunan, dan dokumen Anggaran Pendapatan dan Belanja Negara (APBN) dengan tujuan untuk menyejahterakan rakyatnya sekaligus menyumbang pada kesejahteraan masyarakat dunia. Sejalan dengan Komitmen Indonesia tersebut maka Pemerintah Kota Medan juga tetap mengacu pada MDGs dalam penyusunan program-program kerja Pemerintahan. Hal ini sesuai dengan Salah satu Implementasi dari Inpres No. 3 Tahun 2010, diantara yaitu: Penyusunan Rencana Aksi Daerah (RAD) percepatan pencapaian MDGs di 33 Provinsi dengan rangkaian kegiatan sebagai berikut:

> Penyusunan pedoman teknis Rencana Aksi Daerah (RAD) Provinsi tentang percepatan pencapaian tujuan MDGs untuk memberikan panduan bagi daerah, khususnya provinsi dalam menyusun dokumen rencana aksi percepatan pencapaian target MDGs di daerah, sehingga dapat dihasilkan dokumen rencana aksi yang jelas, operasional dan selaras dengan kebijakan nasional.

> Pelaksanaan fasilitasi penyusunan Rencana Aksi Daerah (RAD) Provinsi oleh Tim Koordinasi MDGs Nasional kepada Tim Koordinasi MDGs Provinsi untuk menyamakan persepsi dalam penyusunan target dan indikator MDGs di tingkat Provinsi dan Kabupaten/Kota, menyusun langkah-langkah penyusunan RAD MDGs Provinsi, dan melakukan exercise penyusunan draft RAD Percepatan Pencapaian Target MDGs di Provinsi termasuk penyusunan target, sasaran dan indikator.

> Penyusunan pedoman teknis Definisi Operasional Indikator MDGs yang berisikan tentang daftar tujuan, target, dan indikator MDGs, konsep definisi, manfaat, metode perhitungan, dan sumber data yang digunakan untuk menyamakan persepsi sehingga data dan informasi MDGs dapat dibandingkan antarprovinsi.

> Penyusunan pedoman penyusunan matrik RAD MDGs kabupaten dan kota sebagai panduan bagi kabupaten dan kota untuk menyusun rencana aksi percepatan pencapaian target MDGs di daerah, sehingga dapat dihasilkan suatu produk dokumen rencana aksi yang jelas, operasional dan selaras dengan kebijakan nasional.

Kewajiban Pemerintah Kota Medan pembuat Program kerja mengacu pada MDGs tertuang pada Surat Edaran Kementerian PPN dan Kemendagri 
Nomor: 0068/M.PPN/02/2012 dan Nomor:050/583/SJ tentang Percepatan Pencapaian Tujuan Pembangunan Milenium (Millennium Development Goals) Tahun 2011-2015 antara lain untuk mendorong agar daerah menyusun program dan kegiatan serta pengalokasian anggaran dalam Rencana Kerja Pembangunan Daerah (RKPD), Rencana Kerja Satuan Kerja Perangkat Daerah (SKPD) dan Rencana Kerja dan Anggaran Satuan Kerja Perangkat Daerah agar mengacu pada RAD MDGs di masing-masing provinsi untuk percepatan pencapaian tujuan target dan indikator MDGs. Adapun kegiatan Hasil yang telah dicapai hingga tahun 2015 di Kota Medan adalah (a) menanggulangi kemiskinan dan kelaparan, (b) mencapai Pendidikan Dasar Untuk semua, (c) mendorong kesetaraan gender dan pemberdayaan perempuan, (d) Menurunkan angka kematian anak, (e) meningkatkan kesehatan ibu, (f) memerangi HIV dan AIDS, (g) malaria dan Penyakit menular lainnya, serta (h) memastikan kelestarian Lingkungan Hidup.

Setelah tahun 2015 maka komunitas internasional di bawah PBB mulai mendiskusikan perumusan agenda pembangunan global pasca 2015. Proses penyusunan agenda pembangunan pasca 2015 ini dilakukan dalam 2 (dua) workstreams yang saling terkait dan bermuara pada satu proses intergovernmental untuk menghasilkan agenda pembangunan pasca 2015, program ini dikenal dengan Sustainable Development Goals (SDGs). Untuk mencermati pelaksanaan Sustainable Development Goals (SDGs) tentunya perlu dievaluasi bagaimana bagaimana kondisi capaian pembangunan di Kota Medan melalui indicator Millienium Development Goals (MDGs) yang secara khusus dalam menanggulangi kemiskinan dan kelaparan (tujuan 1 MGDs) sehingga dapat direkomendasikan beberapa pengukuran program yang dapat mempengaruhi penetapan target capaian Sustainable Development Goals (SDGs) di Kota Medan.

\section{Konsep Tujuan Pembangunan Berkelanjutan (SGDs)}

Konsep pembangunan berkelanjutan bukanlah merupakan pemikiran yang baru. Fauzi (2004) menuliskan bahwa konsep pembangunan berkelanjutan sebenarnya sejak sudah lama menjadi perhatian para ahli. Namun istilah keberlanjutan (sustainability) sendiri memang baru muncul beberapa dekade yang lalu, walaupun perhatian terhadap keberlanjutan sudah dimulai sejak Malthus pada tahun 1798 yang mengkhawatirkan ketersediaan lahan di Inggris akibat ledakan penduduk yang pesat. Satu

QE Journal | Vol.05 - No. 03 September 2016 - 132 
setengah abad kemudian, perhatian terhadap keberlanjutan ini semakin mengental setelah Meadow dan kawan-kawan pada tahun 1972 menerbitkan publikasi yang berjudul The Limit to Growth, yang dalam kesimpulannya mengatakan bahwa pertumbuhan ekonomi akan sangat dibatasi oleh ketersediaan sumber daya alam. Dengan ketersediaan sumber daya alam yang terbatas, arus barang dan jasa yang dihasilkan dari sumber daya alam tidak akan selalu bisa dilakukan secara terus menerus (on sustainable basis).

Konsep pembangunan berkelanjutan telah menjadi konsep yang populer dan fokus dunia internasional sejak dipertegasnya pendekatan ini pada KTT Bumi di Rio de Jenairo pada tahun 1992. Hampir seluruh negara kemudian menggunakan pembangunan berkelanjutan sebagai jargon pembangunannya. Akhir-akhir ini popularitas konsep pembangunan berkelanjutan menjadi semakin mengemuka dengan digadang-gadangnya Sustainable Development Goals (SDGs) sebagai pengganti dari Millennium Development Goals (MDGs) yang berakhir pada tahun 2015. Meskipun mendapat kritikan yang tajam dari para ekonom karena lemahnya fundamental ekonomi yang digunakan dalam model The Limit to Growth, namun buku tersebut cukup menyadarkan manusia akan pentingnya pembangunan yang berkelanjutan. Karena itu perhatian terhadap aspek keberlanjutan ini mencuat kembali ketika pada tahun 1987 World Commission on Environment and Development (WCED) atau dikenal sebagai Brundland Commission menerbitkan buku berjudul Our Common Future. Publikasi ini kemudian memicu \lahirnya agenda baru mengenai konsep pembangunan ekonomi dan keterkaitannya dengan lingkungan dalam konteks pembangunan yang berkelanjutan. Agenda ini sekaligus menjadi tantangan konsep pembangunan ekonomi neoklasik yang merupakan konsep pembangunan konvensional yang selama ini dikenal.

Pembangunan berkelanjutan disepakati sebagai pembangunan yang memenuhi kebutuhan masa kini tanpa mengorbankan hak pemenuhan kebutuhan-kebutuhan generasi yang akan datang. Di dalamnya terkandung dua gagasan penting: (a) gagasan "kebutuhan" yaitu kebutuhan esensial untuk memberlanjutkan kehidupan manusia, dan (b) gagasan keterbatasan yang bersumber pada kondisi teknologi dan organisasi sosial terhadap kemampuan lingkungan untuk memenuhi kebutuhan kini dan hari depan. Pada intinya, pembangunan berkelanjutan 
adalah suatu proses perubahan yang di dalamnya, seluruh aktivitas seperti eksploitasi sumberdaya, arah investasi, orientasi pengembangan teknologi, dan perubahan kelembagaan berada dalam keadaan yang selaras serta meningkatkan potensi masa kini dan masa depan untuk memenuhi kebutuhan dan aspirasi manusia. Jadi tujuan pembangunan ekonomi dan sosial harus diupayakan dengan keberlanjutan. Konsep keberlanjutan merupakan konsep yang sederhana, namun kompleks sehingga pengertian keberlanjutan sangat multidimensi dan multi interpretasi (Fauzi 2009). Menurut Heal dalam Fauzi (2004), konsep keberlanjutan, paling tidak mengandung dua dimensi yaitu pertama, dimensi waktu karena keberlanjutan pasti menyangkut apa yang terjadi di masa mendatang. Kedua, adalah dimensi interaksi antara sistem ekonomi dan sistem sumberdaya alam dan lingkungan. Pezzey (1992) melihat keberlanjutan dari sisi yang berbeda, yaitu melihat dari pengertian statik dan dinamik.

Keberlanjutan statik diartikan sebagai pemanfaatan sumberdaya alam terbarukan dengan laju teknologi yang konstan, sementara keberlanjutan dinamik diartikan sebagai pemanfaatan sumberdaya yang tidak terbarukan dengan tingkat teknologi yang terus berubah. Karena adanya multi dimensi, dan multi interpretasi, maka terdapat dua hal yang secara implisit menjadi perhatian yaitu pertama, menyangkut pentingnya memperhatikan kendala sumberdaya alam dan lingkungan terhadap pola pembangunan dan konsumsi. Kedua, menyangkut perhatian terhadap kesejahteraan (well being) generasi mendatang. Dengan demikian, prinsip pembangunan berkelanjutan dihasilkan dengan memperhatikan 3 aksioma yaitu: (a) perlakukan masa kini dan masa mendatang yang menempatkan nilai positif dalam jangka panjang, (b) menyadari bahwa aset lingkungan memberikan kontribusi terhadap economic well being, dan (c) mengetahui kendala akibat implikasi yang timbul pada aset lingkungan.

Tujuan pembangunan pada hakekatnya adalah untuk meningkatkan kesejahteraan dan kemakmuran masyarakat. Sedangkan "Pembangunan berkelanjutan adalah pembangunan yang memenuhi kebutuhan generasi saat ini tanpa mengurangi kemampuan generasi mendatang untuk memenuhi kebutuhan mereka, dan oleh karena itu Emil Salim menyatakan bahwa pembangunan berkelanjutan bertujuan untuk meningkatkan kesejahteraan masyarakat, untuk memenuhi kebutuhan dan aspirasi manusia. Pembangunan yang berkelanjutan pada hekekatnya ditujukan 
untuk mencari pemerataan pembangunan antar generasi pada masa kini maupun masa mendatang. (Emil Salim,1990)

Pembangunan berkelanjutan mencakup pada upaya untuk mewujudkan terjadinya (1) pemerataan manfaat hasil-hasil pembangunan antar generasi (intergenaration equity) yang berarti bahwa pemanfaatan sumberdaya alam untuk kepentingan pertumbuhan perlu memperhatikan batas-batas yang wajar dalam kendali ekosistem atau sistem lingkungan serta diarahkan pada sumberdaya alam yang replaceable dan menekankan serendah mungkin eksploitasi sumber daya alam yang unreplaceable, (2) Safeguarding atau pengamanan terhadap kelestarian sumber daya alam dan lingkungan hidup yang ada dan pencegahan terjadi gangguan ekosistem dalam rangka menjamin kualitas kehidupan yang tetap baik bagi generasi yang akan datang dan (3) pemanfaatan dan pengelolaan sumberdaya alam semata untuk kepentingan mengejar pertumbuhan ekonomi demi kepentingan pemerataan pemanfaatan sumberdaya alam yang berkelanjutan antar generasi.

Merujukan pada stanner dkk (2009) dn Tusianti (2013) antara ketiga dimensi tersebut dapat disajikan dalam gambar berikut :

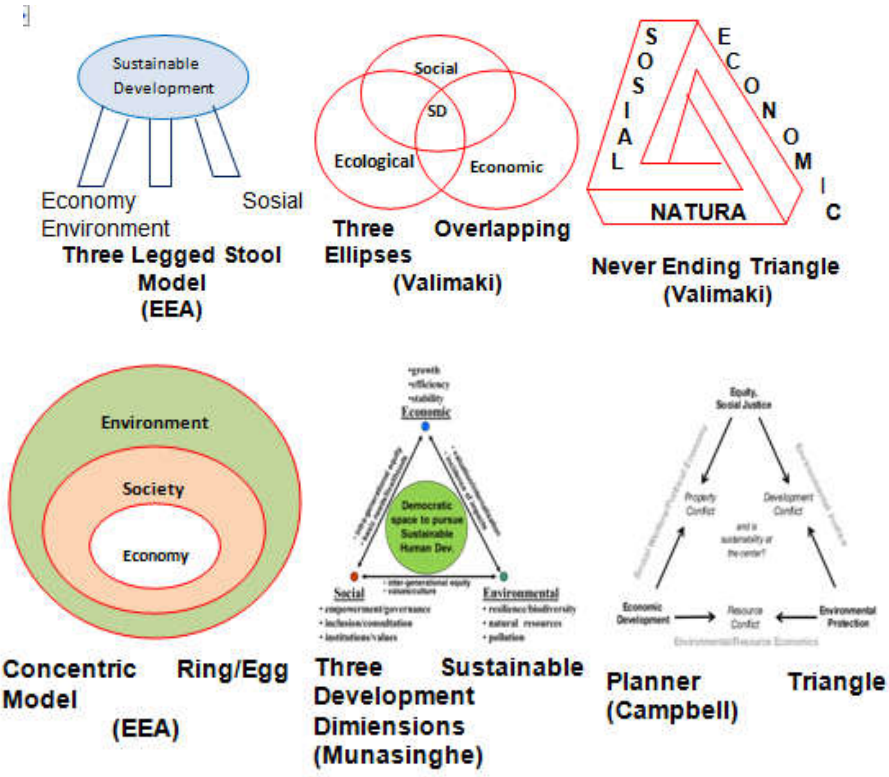

Sumber : Stanner dkk (2009) dan Tusianti (2003)

Gambar 1. Model Pembangunan Berkelanjutan (Ekonomi, Sosial dan Lingkungan)

QE Journal | Vol.05 - No. 03 September 2016 - 135 
Konsep keberlajutan dapat diperinci menjadi tiga aspek pemahaman, yaitu:

1) Keberlajutan ekonomi

Keberlanjutan ekonomi diartikan sebagai pembangunan yang mampu menghasilkan barang dan jasa secara kontinu untuk memelihara keberlajutan pemerintahan dan menghindari terjadinya ketidakseimbangan sektoral yang dapat merusak produksi pertanian dan industri.

2) Keberlajutan lingkungan:

Keberlanjutan lingkungan diartikan sebagai suatu sistem keberlanjutan secara lingkungan harus mampu memelihara sumber daya yang stabil, menghindari eksploitasi sumber daya alam dan fungsi penyerapan lingkungan. Konsep ini juga menyangkut pemeliharaan keanekaraman hayati, stabilitas ruang udara, dan fungsi ekosistem lainnya yang tidak termasuk kategori sumber-sumber ekonomi.

3) Keberlajutan sosial

Keberlanjutan sosial diartikan sebagai sistem yang mampu mencapai kesetaraan, penyediaan layanan sosial termasuk kesehatan, pendidikan, gender, dan akuntabilitas politik.

Berdasarkan konsep pembangunan berkelanjutan tersebut, maka indikator pembangunan berkelanjutan tidak akan terlepas dari aspek-aspek tersebut diatas, yaitu aspek ekonomi, ekologi/lingkungan, sosial, politik, dan budaya. (Askar Jaya, 2004)

a. Keberlanjutan Ekologis

Keberlanjutan ekologis akan menjamin keberlanjutan ekosistem bumi.

b. Keberlanjutan Ekonomi

Keberlanjutan ekonomi makro menjamin kemajuan ekonomi secara berkelanjutan dan mendorong efisiensi ekonomi melalui reformasi struktural dan nasional.

c. Keberlanjutan Ekonomi Sektoral

Untuk mencapai keberlanjutan ekonomi sektoral, berbagai kasus dilakukan terhadap kegiatan ekonomi.

QE Journal | Vol.05 - No. 03 September 2016 - 136 


\section{d. Keberlanjutan Sosial Budaya}

Keberlanjutan sosial dan budaya mempunyai empat sasaran yaitu (i) Stabilitas penduduk, (ii) memenuhi kebutuhan dasar manusia, (iii) mempertahankan keanekaragaman budaya, (iv) mendorong pertisipasi masyarakat lokal dalam pengambilan keputusan, (v) Keberlanjutan Politik dan (vi) Keberlanjutan Pertahanan dan Keamanan

\section{METODOLOGI PENELITIAN}

Jenis data yang digunakan adalah data-data yang terkait dengan tingkat capaian dari setiap indikator MGDs dari tahun 2010-2015, sedangkan sumber data yang digunakan adalah berbagai sumber yang bisa digali dari Medan Dalam Angka, Sumatera Dalam Angka, Statistik Daerah Kota Medan, Indikator Kesejahteraan dan berbagai laporan kegiatan dari setiap SKPD terkait dengan ruang lingkup kajian ini terdiri dari evaluasi capaian pembangunan di Kota Medan melalui indicator Millienium Development Goals (MDGs) yang dapat mempengaruhi penetapan target capaian Sustainable Development Goals (SDGs) sedangkan teknik analisis data yang digunakan melakukan pendekatan yang pendekatan kuantitatif, namun dalam cakupan analisis deskriptif dengan cara melakukan eksplorasi data berupa tabel dan grafik. Pemaparan disesuaikan dengan pedoman dari setiap indikator yang ada diseiap target capaian Capaian Millenium Development Goals (MDGs)

\section{HASIL DAN PEMBAHASAN}

Hasil kajian atas capaian MGDs di Kota Medan terkait dengan tujuan 1 MGDs dalam menanggulangi kemiskinan dan kelaparan ditunjukkan dalam tabel berikut :

Tabel 1. Pencapaian MGDs Bidang Kemiskinan dan kelaparan

\begin{tabular}{llllll}
\hline Indikator & 2010 & 2014 & $\begin{array}{l}\text { Target } \\
\text { MDGs 2015 }\end{array}$ & Status & $\begin{array}{l}\text { Sumb } \\
\text { er }\end{array}$
\end{tabular}

Tujuan 1. Menanggulangi Kemiskinan dan Kelaparan

Target 1A: Menentukan hingga setengahnya proporsi penduduk dengan tingkat pendapatan kurang dari USD 1 (PPP) per hari dalam kurun waktu 1990-2015

\begin{tabular}{lllllll}
\hline 1.1 & $\begin{array}{l}\text { Tingkat } \\
\text { berdasarkan }\end{array}$ & Kemiskinkan \\
kemiskinan nasional & garis & $10.05 \%$ & $9,12 \%$ & $8,75 \%$ & & BPS \\
& & & & $9,41 \%$ &
\end{tabular}

QE Journal | Vol.05 - No. 03 September 2016 - 137 


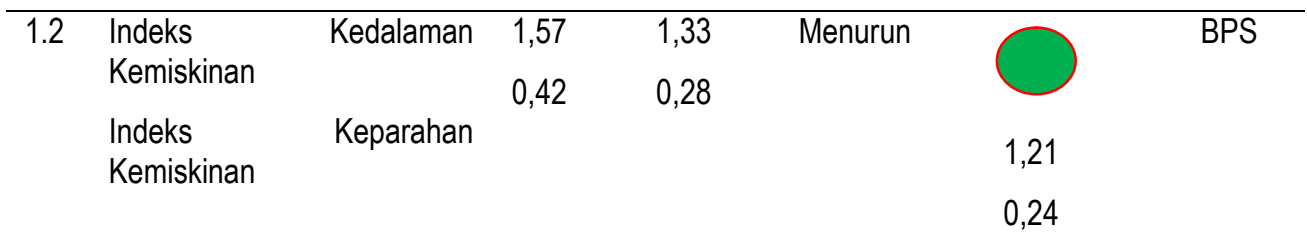

Target 1B. Mewujudkan kesempatan kerja penuh dan pekerjaan yang layak untuk semua, termasuk
perempuan dan kaum muda.

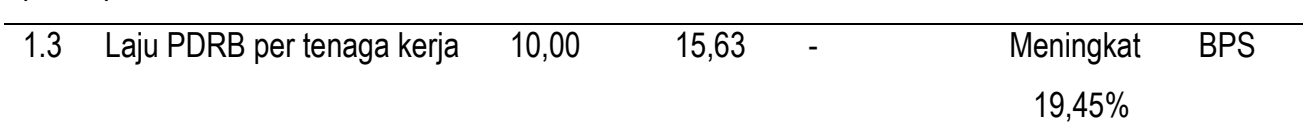

\begin{tabular}{llllll}
\hline 1.4 & $\begin{array}{l}\text { Rasio kesempatan kerja } \\
\text { terhadap penduduk usia 15 } \\
\text { tahun ke atas }\end{array}$ & $80,14 \%$ & Menurun & BPS \\
& & & $53,65 \%$ & \\
\hline 1.5 & $\begin{array}{l}\text { Proporsi tenaga kerja yang } 20,23 \% \\
\text { berusaha sendiri dan } \\
\text { pekerja bebas keluarga } \\
\text { terhadap total kesempatan } \\
\text { kerja }\end{array}$ & $72,94 \%$ & & BPS \\
\hline
\end{tabular}

Target 1C. Menurunkan hingga setengahnya proporsi penduduk yang menderita kelaparan dalam kurun waktu 1990-2015

\begin{tabular}{|c|c|c|c|c|c|c|}
\hline 1.6 & $\begin{array}{l}\text { Prevalensi Balita dengan } \\
\text { berat } \\
\text { rendah/kekurangan gizi }\end{array}$ & $0,12 \%$ & 0,20 & $14,05 \%$ & $0,22 \%$ & BPS \\
\hline 1.7 & Prevalensi balita gizi buruk & $0,15 \%$ & $0,02 \%$ & $2,15 \%$ & $0,05 \%$ & BPS \\
\hline 1.8 & Prevalensi balita gizi kurang & $5,48 \%$ & $0,43 \%$ & $11,90 \%$ & $0,43 \%$ & BPS \\
\hline
\end{tabular}

\begin{tabular}{lll}
\hline 1.9 & Proporsi penduduk dengan & $(2012)^{*}$ \\
asupan dibawah kalori \\
tingkat konsumsi minimum : \\
-1.400 kkal/kapita/hari \\
\end{tabular}

QE Journal | Vol.05 - No. 03 September 2016 - 138 


\begin{tabular}{lll} 
& $58,14 \%$ & $35,32 \%$ \\
\hline Status : & Belum Tercapai
\end{tabular}

Target capaian tujuan 1A yang berupaya untuk menurunkan proporsi penduduk dengan tingkat pendapatan kurang dari USD 1 (PPP) per hari dalam kurun waktu 1990-2015 di Kota Medan, dari sisi penurunan tingkat kemiskinan berdasarkan garis kemiskinan nasional belum tercapai sesuai dengan target MDGs 2015 yaitu sebesar 8,75, namun tingkat kemiskinan di Kota Medan dalam (5) lima tahun terakhir dari tahun 2010 hingga tahun 2015 menunjukkan progress yang cukup baik, dimana jumlah penduduk miskin dan presentasi penduduk miskin (\%) mengalami penurunan dari tahun 2010 ke 2015, walaupun untuk setiap tahunnya mengalami trend yang berfluktuasi mengalami kenaikan dan penurunan pada tahun tahun tertentu seperti ditunjukkan dalam Gambar 2.

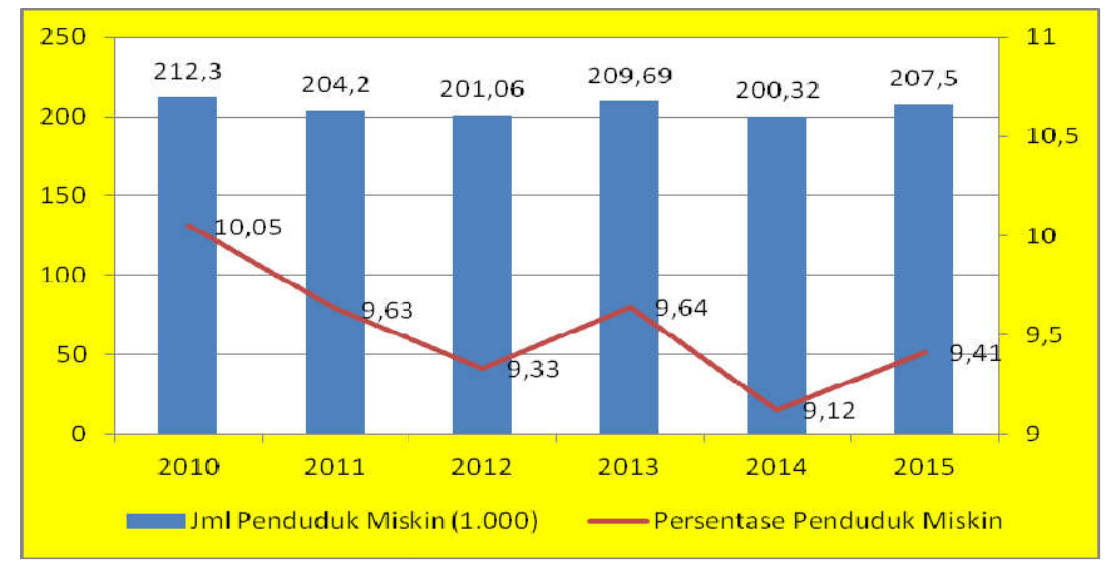

Sumber : BPS Kota Medan

Gambar 2.Trend Jumlah Penduduk dan \% Penduduk Miskin Kota Medan 2010-2015

Berdasarkan Gambar 2 ditunjukkan bahwa persentase penduduk miskin di Kota Medan menunjukkan kecenderungan penurunan. Pada tahun 2010 persentase penduduk miskin di Kota Medan sebesar 10,05 persen turun menjadi 9,41 persen pada tahun 2015. Namun, selama rentang waktu tahun 2010-2015, angka kemiskinan mengalami kenaikan dari 9,33 persen pada tahun 2012 menjadi 9,64 persen pada tahun 2013, kemudian 
mengalami kenaikan lagi dari 9,12 persen pada tahun 2014 menjadi 9,41 persen pada tahun 2015.

Indikator lain yang digunakan untuk melihat kemiskinan di suatu daerah yaitu indeks kedalaman kemiskinan (poverty Gap Indek-P1) yang merupakan ukuran rata-rata kesenjangan pengeluaran masing masing penduduk miskin terhadap garis kemiskinan. Semakin tinggi nilai indeks, semakin jauh rata-rata pengeluaran dari kemiskinan. Sedangkan indeks keparahan kemiskinan (Poverty Severity Index-P2) memberikan gambaran mengenai penyebaran pengeluaran diantara penduduk miskin. Semakin tinggi nilai indeks, semakin tinggi ketimpangan pengeluaran diantara penduduk miskin. Kondisi indeks kedalaman kemiskinan dan keparahan kemiskinan di Kota medan ditunjukkan dalam gambar 3 berikut.

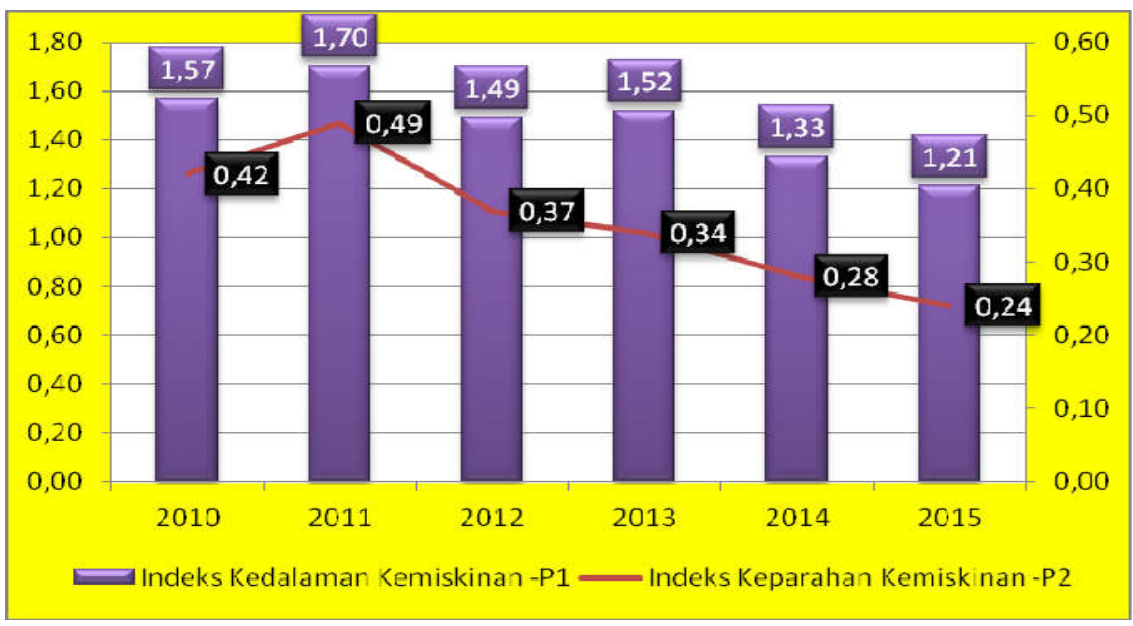

Sumber : Data dan Informasi Kemiskinan Berdasarkan Kab/Kota (berbagai tahun, BPS)

Gambar 3. Indeks Kedalaman Kemiskinan dan Indeks Keparahan Kemiskinan Kota Medan 2010-2015

Berdasarkan Gambar 3 ditunjukkan bahwa data indeks kedalamam kemiskinan Kota Medan pada tahun 2010 sebesar 1,57 kemudian pada tahun 2011 terjadi kenaikan menjadi 1,70. Pada tahun 2012 sejalan dengan kondisi jumlah penduduk miskin di Kota Medan terjadi penurunan indeks kedalaman kemiskinan menjadi 1,49, namun meningkat lagi pada tahun 2013 menjadi 1,52 dan untuk tahun 2014 hingga 2015 kembali mengalami penurunan masing-masing menjadi 1,33 dan 1,21. Penurunan nilai indeks Kedalaman Kemiskinan di Kota Medan ini mengindikasikan bahwa rata-rata pengeluaran penduduk miskin cenderung makin 
mendekati garis kemiskinan dan ketimpangan pengeluaran penduduk miskin juga semakin menyempit. Sedangkan untuk posisi indeks keparahan kemiskinan di Kota Medan, pada tahun 2010 sebesar 0,42 dan meningkat pada tahun 2011 menjadi 0,49, namun sejak tahun 2012 hingga 2015 indeks keparahan kemiskinan di Kota Medan terus mengalami penurunan hingga di tahun 2015 menjadi sebesar 0,24. Hal ini mengindikasikan bahwa bahwa dengan semakin rendahnya nilai nilai indeks keparahan kemiskinan, maka semakin rendah tingkat ketimpangan pengeluaran diantara penduduk miskin di Kota Medan. Kondisi terjadinya penurunan indeks kedalaman kemiskinan dan indeks keparahan kemiskinan di Kota Medan ini mengindikasikan bahwa berbagai program kegiatan yang dilakukan oleh Kota Medan telah sesuai dengan target dari MGDs yang ditetapkan hingga tahun 2015 yaitu adanya penurunan indeks kedalaman kemiskinan.

Target 1B yang berupaya untuk mewujudkan kesempatan kerja penuh dan pekerjaan yang layak untuk semua, termasuk perempuan dan kaum muda ini, indikator pertama yaitu dari kecepatan pertumbuhan produktivitas tenaga kerja di Kota medan melalui laju PDRB per tenaga kerja, kedua dari rasio kesempatan kerja terhadap terhadap penduduk usia 15 tahun ke atas dan ketiga dari Proporsi tenaga kerja yang berusaha sendiri dan pekerja bebas keluarga terhadap total kesempatan kerja. Perkambangan laju pertumbuhan PDRB per tenaga kerja di Kota Medan ditunjukkan dalam tabel 2 dan gambar 4. berikut :

Tabel 2. Laju PDRB per tenaga kerja di Kota Medan 2010-2015

\begin{tabular}{|r|r|r|r|r|}
\hline \multirow{2}{*}{ Tahun } & PDRB ADHB 2010 & Jumlah Tenga Kerja & $\begin{array}{r}\text { PDRB per } \\
\text { tenaga kerja } \\
\text { (Milyar Rupiah) }\end{array}$ & $\begin{array}{c}\text { Laju PDRB per } \\
\text { tenaga kerja } \\
\text { (Orang) }\end{array}$ \\
\hline 2010 & $90.615,46$ & 1.020 .626 & 0,0888 & \\
\hline 2011 & $104.059,43$ & 1.002 .013 & 0,1039 & 16,97 \\
\hline 2012 & $117.487,21$ & 936.143 & 0,1255 & 20,85 \\
\hline 2013 & $131.323,82$ & 1.004 .899 & 0,1307 & 4,13 \\
\hline 2014 & $147.325,15$ & 974.951 & 0,1511 & 15,63 \\
\hline 2015 & $164.628,27$ & 912.037 & 0,1805 & 19,45 \\
\hline
\end{tabular}

Sumber : Medan Dalam angka (Diolah)

QE Journal | Vol.05 - No. 03 September 2016 - 141 


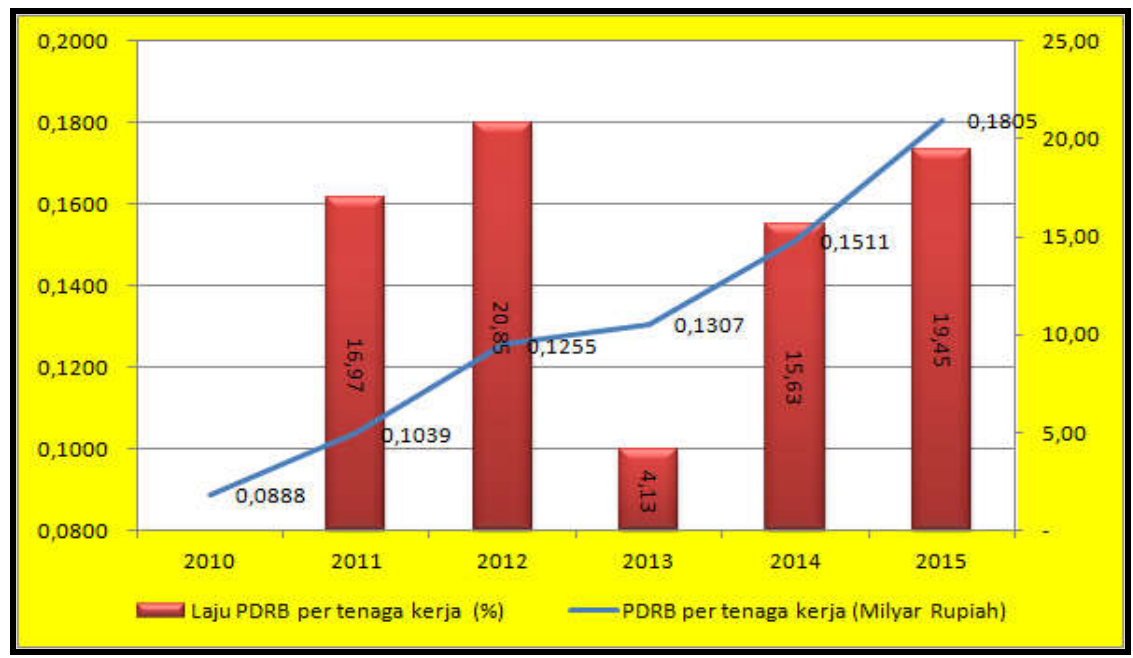

Sumber : Medan Dalam angka (Diolah)

Gambar 4. Laju PDRB per tenaga kerja di Kota Medan 2010-2015

Berdasarkan Tabel 2 dan Gambar 4 ditunjukkan bahwa jika dilihat dari sisi produktivitas tenaga kerja di Kota Medan setiap tahunnya mengalami peningkatan dimana pada tahun 2010 hanya sebesar 0,0888 (dalam milyar Rp/Jiwa) naik menjadi 0,1805 (dalam milyar Rp/Jiwa) pada tahun 2015 atau terjadi peningkatan dari tahun 2010 ke 2015 hingga 103,31\%, namun jika dilihat dari lajunya setiap tahun, pada tahun 2013 mengalami penurunan dari 20,85\% pada tahun 2012 menjadi 4,13\%, dan sejak tahun 2013 hingga tahun 2015 laju PDRB per tenaga kerja mengalami peningkatan hingga di tahun 2015 tumbuh sebesar 19,45\%. Dari tabel di atas, pertumbuhan produktivitas tenaga kerja tertinggi terjadi pada tahun 2011-2012 yaitu sebesar 20,85, sedangkan terendah terjadi pada tahun 2012-2013 yaitu sebesar 4,13. Pertumbuhan tinggi disebabkan terjadinya penurunan jumlah tenaga kerja yang bekerja sementara Pendapatan Daerah Regional Bruto (PDRB) mengalami peningkatan yang cukup tinggi. Sebaliknya, terjadi peningkatan tenaga kerja dan laju PDRB mengalami penurunan di tahun 2012-2013 sehingga menyebabkan pertumbuhan produktivitas tenaga kerja menjadi menurun.

Untuk rasio kesempatan kerja terhadap penduduk usia 15 tahun ke atas dicapai program MGDs di Kota Medan dari tahun 2010-2015 ditunjukkan dalam Gambar 5, dimana dalam gambar tersebut ditunjukkan bahwa berfluktuasi. Pada tahun 2010 rasionya sebesar 53,82 persen dan 
meningkat pada tahun 2011 menjadi 60,42\%. Selanjutnya sejak tahun 2013 hingga 2015 terus mengalami penurunan hingga di tahun 2015 menjadi $53,65 \%$. Hal ini menunjukkan bahwa tingkat penyerapan tenaga kerja terhadap total penduduk usia kerja di Kota Medan mengalami penurunan, yang mungkin disebabkan oleh beberapa faktor diantaranya adalah perkembangan jumlah penduduk dan angkatan kerja, pertumbuhan ekonomi, tingkat produktivitas tenaga kerja dan kebijaksanaan mengenai penyerapan tenaga kerja itu sendiri.

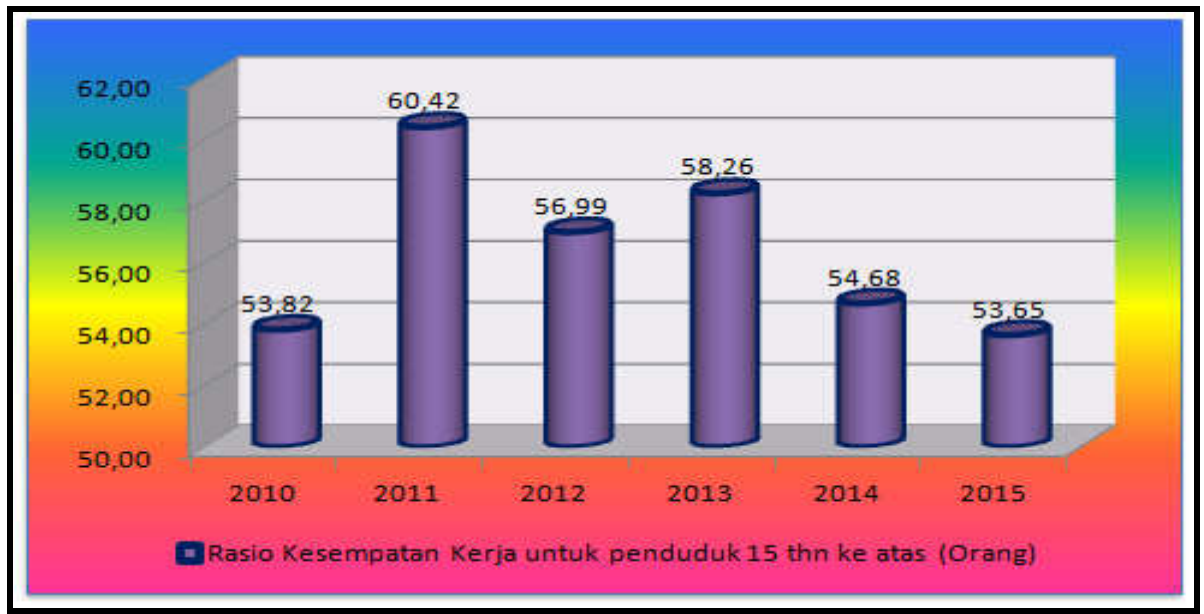

Sumber : Medan Dalam angka (Diolah)

Gambar 5. Rasio Kesempatan Kerja Untuk Penduduk 15 thn ke atas Di Kota Medan 2010-2015

Sementara itu untuk tingkat capaian proporsi tenaga kerja yang berusaha sendiri dan pekerja bebas keluarga terhadap total kesempatan kerja merupakan proporsi penduduk usia $15+$ yang bekerja yang berstatus berusaha sendiri dan pekerja bebas terhadap total penduduk15+ yang bekerja, dinyatakan dalam persentase ditunjukkan dalam gambar 6 . Dalam gambar 6 tersebut ditunjukkan bahwa capaian proporsi untuk tahun 2015 belum tercapai karena di tahun 2015 hanya sebesar 23,70 persen, walaupun mengalami kenaikan dari tahun 2010 yang sebesar $20,23 \%$. 


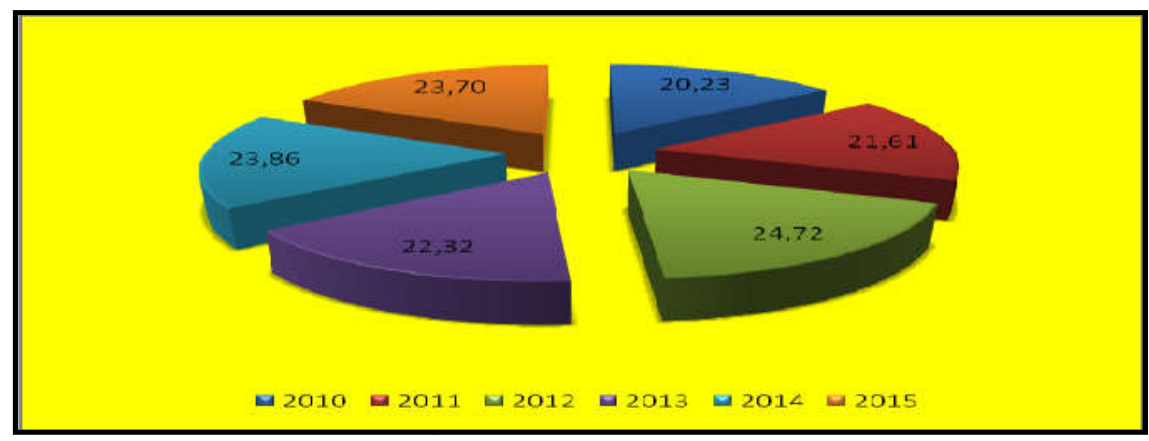

Sumber: Medan dalam angka (diolah)

Gambar 6. Proporsi Tenaga Kerja yang berusaha sendiri dan Pekerja Bebas terhadap Total Kesempatan kerja Kota Medn 2010- 2015

Capaian target 1C yang berupaya untuk menurunkan hingga setengahnya proporsi penduduk yang menderita kelaparan dalam kurun waktu 19902015 ditunjukkan dalam tabel 3 dan gambar 7 .

Tabel 3. Persentase Balita Prevalensi Gizi Kurang dan Gizi Buruk

\begin{tabular}{|r|r|r|r|r|r|}
\hline \multirow{2}{*}{ Tahun } & \multirow{2}{*}{ Jumlah Balita } & \multicolumn{2}{|c|}{ Gizi Kurang } & \multicolumn{2}{c|}{ Gizi Buruk } \\
\cline { 3 - 6 } & & Jumlah & \multicolumn{1}{c|}{$\%$} & Jumlah & \multicolumn{1}{c|}{$\%$} \\
\hline 2010 & 139.294 & 7.637 & 5,48 & 210,00 & 0,15 \\
\hline 2011 & 147.790 & 4.213 & 2,85 & 864,00 & 0,58 \\
\hline 2012 & 193.881 & 1.367 & 0,71 & 124,00 & 0,06 \\
\hline 2013 & 263.397 & 1.022 & 0,39 & 65,00 & 0,02 \\
\hline 2014 & 339.375 & 1.446 & 0,43 & 84,00 & 0,02 \\
\hline 2015 & 202.053 & 868 & 0,43 & 111,00 & 0,05 \\
\hline Sumber : Medan dalam angka, 2016 & & & \\
\hline
\end{tabular}

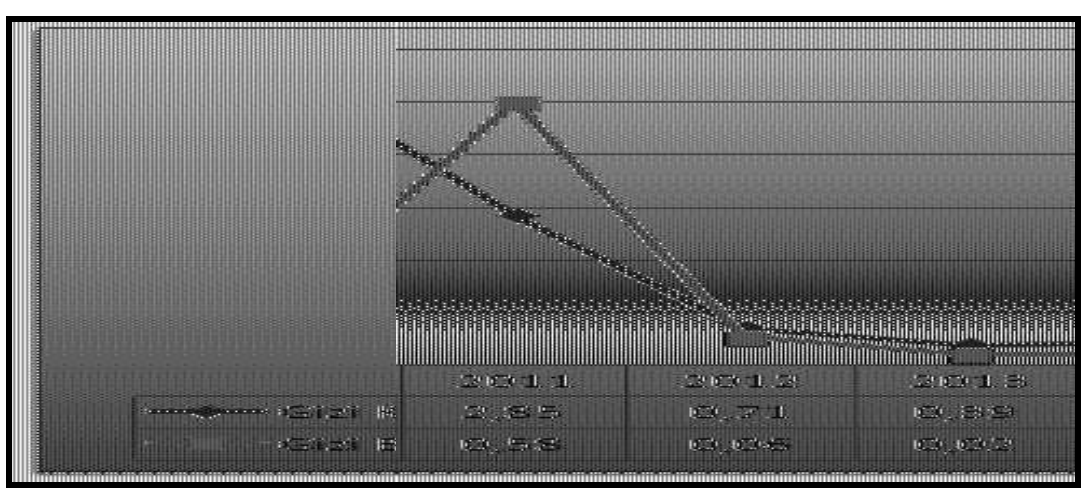

Sumber : Medan dalam angka, 2016

Gambar 7. Persentase Balita Prevalensi Gizi Kurang dan Gizi Buruk

QE Journal | Vol.05 - No. 03 September 2016 - 144 
Kondisi prevalensi balita dengan gizi kurang dan gizi buruk pada tahun 2015 adalah sebesar 0,22\% dan 0,05\% menunjukkan bahwa targer MDGs sudah tercapai, dimana target MDGs tahun tersebut sebesar 2,15\% dan $11,90 \%$. Perkembangan tingkat ketercapaian prevalensi untuk balita gizi buruk dan gizi kurang ditunjukkan dalam gambar 4.3. Namun prevalensi balita dengan berat badan rendah yang ditahun 2010 sebesar 0,12\% mengalami peningkatan menjadi sebesar $0,22 \%$, walaupun persentase tersebut jika dibandingkat dengan target MDGs tahun 2015 sebesar 14,05\% berarti hal itu juga menunjukkan sudah tercapai.Tercapainya semua target MDGs di kota Medan pada tahun 2015 bukan berarti bahwa programprogram untuk menekan jumlah balita gizi buruk dan gizi kurang dihentikan, karena hal ini akan berbanding lurus dengan tingkat kemiskinan di Kota Medan.

Tahun 2017, Indonesia bersiap menjalankan program Sustainability Development Goals (SDGs) dari PBB hingga tahun 2030 nanti. Program ini bercita-cita untuk menghapus kemiskinan di dunia. SDGs merupakan kelanjutan dari program Millenium Development Goals (MDGs), juga dari PBB, yang dicanangkan berlaku di Indonesia sejak tahun 2000 hingga 2015. Berbeda dengan MDGs, program SDGs menaruh perhatian bukan hanya pada pengembangan manusia (human development) tapi juga pengembangan ekonomi dan lingkungan sebagai bagian dari agendanya. Berbeda pula dengan MDGs yang bersifat top-down, SDGs disusun dengan melibatkan negara-negara yang memberlakukan SDGs, baik itu dari pemerintah maupun masyarakat sipil. Hasil dari pelibatan itu adalah 17 indikator yang mesti dicapai negara pemberlaku SDGs dalam 15 tahun ke depan.

Untuk mengakhiri segala bentuk kemiskinan di manapun di kota Medan, maka program kegiatan di Kota Medan seyogya dapat diarahkan untuk mencapai Medan bebas dari kemiskinan (Menanggulangi kemiskinan dan kelaparan) dengan sasarannya adalah menurunkan tingkat kemiskinan dan penanggulangan penyandang masalah kesejahteraan sosial serta meningkatkan ketahanan pangan. Untuk mencapai sasaran tersebut indikator yang dapat dijadikan acuannya adalah terjadinya (1) penurunan persentase penduduk miskin, (2) perubahan status dari keluarga pra sejahtera menjadi keluarga sejahtera I dan (3) persentase PMKS yang memperoleh bantuan sosial meningkat serta (4) meningkatnya 
ketersediaan pangan utama. Program yang dapat dijalankan untuk mencapai sasaran dengan indikator tersebut diantaranya adalah sebagai berikut :

a. Program Pemberdayaan Fakir Miskin, Komunitas Adat Terpencil (KAT) dan Penyandang Masalah Kesejahteraan Sosial (PMKS) Lainnya.

b. Program Pelayanan dan rehabilitasi kesejahteraan sosial

c. Program Pemberdayaan Kelembagaan Kesejahteraan Sosial

d. Program Peningkatan Ketahanan Pangan

e. Program Penanggulangan Kemiskinan

f. Program Diversifikasi dan Peningkatan Ketahanan Pangan

g. Program lainnya yang terkait dengan tujuan 1 .

Mengakhiri kelaparan, mencapai ketahanan pangan dan meningkatkan gizi, serta mendorong pertanian yang berkelanjutan. Untuk mengakhiri segala bentuk kelaparan, mencapai ketahanan pangan dan meningkatkan gizi, serta mendorong pertanian yang berkelanjutan di kota Medan, maka program kegiatan di Kota Medan seyogya dapat diarahkan untuk mencapai sasaran peningkatan akses kesehatan dan kualitas pelayanan kesehatan, peningkatan kesehatan bayi, balita dan anak, peningkatan kesehatan ibu, sedangkan untuk mendrong pertaian yang berkelanjutan diarahkan untuk peningkatan produktivitas masyarakat petani. Adapun program kegiatan yang dapat dikembangkan diantaranya adalah sebagai berikut :

a. Penciptaan inovasi teknologi tepat guna untuk optimalisasi lahan pertnian dengan programnya adalah pemberdyaan penyuluh pertanian

b. Pemanfaatan lahan terlantar, lahan marjinal dan lahan pekarangan rumah dengan programnya seperti Produktivitas padi atau bahan pangan utama

c. Peningkatan produksi perikanan dengan program Optimalisasi Produksi perikanan Konsumsi Ikan

d. Program Upaya Kesehatan Masyarakat untk mencapai peningkatkan akses dan kualitas pelayanan kesehatan dasar dan rujukan

e. Program Peningkatan Kualitas Pelayanan Kesehatan Rumah Sakit

f. Program Keluarga Berencana

g. Peningkatan pelayanan kesehatan terhadap neonatal, balita dan anak usia sekolah

h. Program Perbaikan Gizi Masyarakat

i. Peningkatan akses dan mutu pelayanan kesehatan ibu hamil

QE Journal | Vol.05 - No. 03 September 2016 - 146 
j. Program lainnya yang terkait dengan tujuan 2 .

\section{SIMPULAN DAN SARAN}

\section{Simpulan}

Kondisi capaian pembangunan di Kota Medan melalui indicator Millienium Development Goals (MDGs) pada dasarnya sudah berjalan dengan baik dimana dari 7 indikator yang dicanangkan sebagain besar kegiatan sudah tercapai, diantaranya yaitu :

Tujuan 1. Menanggulangi Kemiskinan dan Kelaparan pada umumnya sudah tercapai yaitu terkait dengan Indeks Kedalaman Kemiskinan, Indeks Keparahan Kemiskinan, Laju PDRB per tenaga kerja, Rasio kesempatan kerja terhadap penduduk usia 15 tahun ke atas, Prevalensi Balita dengan berat badan rendah/kekurangan gizi , Prevalensi balita gizi buruk, Prevalensi balita gizi kurang kecuali untuk tingkat kemiskinan berdasarkan garis kemiskinan nasional, Proporsi tenaga kerja yang berusaha sendiri dan pekerja bebas keluarga terhadap total kesempatan kerja belum tercapai.

\section{$\underline{\text { Saran }}$}

Komitmen pencapaian Sustainable Development Goals (SDGs) sebagai kelanjutan dari Millenium Development Goals (MDGs) harus menjadi dasar dalam proses pembangunan di Kota Medan, karena lebih dari 15 tahun terakhir, delapan tujuan dan 60 target MDGs telah melahirkan perbaikan yang signifikan dalam pembangunan di tingkat nasional, regional dan global termasuk di Kota Medan. Keberlanjutan dari berbagai program MGDs harus terus dijaga dan ditingkatkan sehingga pelaksanaan program SGDs dapat berjalan secara optimal dengan cara melakukan penguatan terhadap berbagai program kegiatan yang dapat mencapai target SGDs di Kota Medan.

\section{Daftar Pustaka}

Fauzi, N., dan Zakaria, Y., (2000). Mensiasati Otonomi Daerah. Konsorsium Pembaharuan Agraria bekerjasama dengan INSIST Press. Yogyakarta.

Jaya, askar. Makalah individu Pengantar Falsafah Sains Semester ganjil IPB, 2004 diakses dalam web site 
Pezzey, J. (1992) Sustainable Development Concepts: An Economic Analysis, the World Bank Publication, Washington D.C

Stanner D, Dom A, Gee D, Martin J, Riberio T, Rickard L dan Weber JL. 2009. Frame-works for Policy Integration Indicator for Sustainable Development ang for Evaluating Complex Scientific Evidence. Dalam Hak T, Moldan B, Dahl AL (Ed.) Sustainability Indicators: A Scientifi Assessment. Scientific Committee on Problem of the Environment (SCOPE).

Salim, Emil. 1990, Konsep Pembangunan Berkelanjutan, Jakarta.

Tusianti E. 2013. Synergistic Development Performance In Indonesia Making Sustainable Development Practical.[Tesis]. Bandung: Insitut Teknologi Bandung dan University of Groningen 